\title{
SISTEMAS DE EXCLUSIÓN Y VIOLENCIA EN RELATOS DE LOS SALVADOREÑOS MANLIO ARGUETA Y CLAUDIA HERNÁNDEZ
}

\author{
Hilda Gairaud R.
}

\begin{abstract}
RESUMEN
El presente artículo examina la exclusión identitaria como una forma de violencia que, a menudo, se encuentra oculta o invisibilizada en el discurso. En este caso, las manifestaciones de este tipo de violencia se abordan partiendo de los efectos que tuvo el proyecto moderno europeo y la colonialidad en la región centroamericana. Además, se evidencian estas manifestaciones en textos literarios de dos autores con el fin de revelar cómo está representada la exclusión en el período postrevolucionario en El Salvador. Tanto las técnicas literarias como el estilo de los escritores se asocian con el sistema de degradaciones discutido por Mijail Bajtín e ilustran, de formas diversas, la subjetividad de dicho país centroamericano.

Palabras clave: identidad, subjetividad, modernidad, colonialidad, exclusión, degradación.
\end{abstract}

\begin{abstract}
The following article examines exclusion based on predominant types of identity as a means of violence that sometimes is hidden, obscured, or blurred in discourse. In this case, the manifestations of this type of violence are explored taking into consideration the effects of the European modernity and the colonial processes in the Central American region. In addition, violence is evidenced in texts written by two writers with the aim of revealing the ways of representing exclusion in the post-revolutionary period in El Salvador. Both the literary devices and the style employed by these authors are associated to the systems of degradations discussed by Mijail Bajtín and they illustrate, in diverse ways, the subjectivity of this Central American country.

Key words: identity, subjectivity, modernity, colonization, exclusion, degradation.
\end{abstract}

\section{Introducción}

La concepción de la subjetividad predominante que teóricamente se ha manejado en la región centroamericana ha estado marcada por la influencia de varios eventos históricos derivados de la modernidad europea como lo son: el uso de la razón crítica asociada al conocimiento y al

ML. Hilda Gairaud R. Profesora adjunta. Literatura Inglesa. Universidad de Costa Rica. Correo electrónico: hgairaud@yahoo.com

Recepción: 2- 09- 2010

Aceptación: 5- 11- 2010 
desarrollo de las disciplinas y de las ciencias, la expansión del capitalismo, el establecimiento de la industria cultural, los cambios tecnológicos y la colonización de América. Todos estos agentes han contribuido a constituir una subjetividad y políticas identitarias ${ }^{1}$ hegemónicas en el área.

Sin embargo, es la colonidad, según la ha definido Mignolo (2005), el factor que tuvo mayor impacto durante el proceso de la constitución de la subjetividad en América. El efecto de la colonialidad genera la idea de la región desde el punto de vista europeo. América es articulada desde la perspectiva europea como un mundo incivilizado y bárbaro, el cual los europeos deben intervenir para cambiarlo. Agrega Mignolo (2005) que "el continente americano es el resultado de la primera expansión comercial europea y el motor del capitalismo" (18) que fomentó el genocidio de los indios y los esclavos y que estableció el eurocentrismo como el primer orden mundial moderno. De este modo, el proyecto eurocentrista obliga a "civilizar" a los habitantes originarios de América imponiendo los esquemas sociales de Europa, de manera que quedan anuladas las identidades nativas y se acreditan las primeras evidencias de exclusión identitaria.

Además, según Santiago Castro (2005), las élites criollas implantaron -en el área- la concepción de identidad de la ciencia ilustrada al establecer un grupo dominante frente a los mestizos, negros e indígenas y configuraron así el "imaginario de la blancura como el primer imaginario geo-cultural del sistema mundo” (441). Este grupo político legitimó la exclusión sistemática y, consecuentemente, definió la otredad. Los indicios de exclusión derivados del proyecto de la modernidad europeo han continuado evolucionando en la región y sigue influyendo en la conformación de las subjetividades excluidas, principalmente, al promover la marginalidad a partir de características fenotípicas.

La presente investigación aborda la exclusión como un tipo de violencia cultural y estructural, a menudo invisibilizada, ejercida sobre los sujetos y sujetas diferentes u otros, llamados, también, subalternos ${ }^{2}$. Además, mediante la aplicación de métodos del análisis crítico del discurso, se abordará y analizará la exclusión y la violencia en una muestra de textos escritos por los salvadoreños Claudia Hernández y Manlio Argueta.

\section{La exclusión identitaria, los procesos históricos de violencia militar en Centroamérica y la literatura de posguerra}

El proyecto (pos)moderno occidental propicia la construcción de las subjetividades en América sobre el fundamento de la inferioridad racial y, además, impone la automatización y la enajenación con el fin de expandir la subjetividad eurocentrista. El hecho de anular la subjetividad nativa de los indios fomenta, en el continente, la creación de sistemas de exclusión. De hecho, en el pasado, y hasta el presente, las identidades nativas no solo han sido marginalizadas y segregadas, sino también colonizadas. Por ejemplo, en Guatemala se incentiva la raza "ladina"3 y el blanqueamiento mediante el mestizaje como método que permite a los sujetos y sujetas distanciarse del origen maya.

Arturo Arias (1998: 24) afirma que en la región centroamericana, al finalizar la Segunda Guerra Mundial, se inició una "fase desarrollista modernizante" que se aceleró con la influencia de eventos como la Revolución cubana, los movimientos de izquierda emergentes en la región y la creación del Mercado Común Centroamericano. Estos hechos impulsaron la creación de un estado autoritario que, según Arias (1998: 24), limitó la inserción de nuevos actores sociales al proceso político y motivó la violencia estructural y militar en tres países: 
Guatemala, El Salvador y Nicaragua. Durante la época de los años 80, cubanos y soviéticos respaldaron a los grupos insurgentes que pelearon largas y sangrientas guerras contra las fuerzas derechistas, apoyadas -mayormente- por el gobierno estadounidense. Sin embargo, al finalizar la Guerra Fría, en 1991, las superpotencias de aquel entonces retiraron su ayuda militar a la región (Arana 88) y opacaron, así, las intensas luchas bélicas.

En El Salvador, la situación social -antes de empezar la guerra- era ya complicada, debido a la influencia de la modernización, cuyos efectos se manifestaron en desigualdad, exclusión y marginalización. En ese país, la concentración de la tierra y la riqueza estaba en manos de unos pocos. Así, el indicador de la brecha entre ricos y pobres señalaba que el $10 \%$ de la población disfrutaba del $80 \%$ de las riquezas del país. La tensión aumentó debido a las repercusiones de los conflictos entre Occidente, Estados Unidos -principalmente- y el bloque comunista (Ensayo de la guerra civil de El Salvador 2009). En El Salvador, los movimientos del sector obrero y campesino, el grupo armado llamado Frente Farabundo Martí para la Liberación Nacional (FMLN) y la resistencia representada por los grupos que estaban en el poder (el estado, los militares y la clase oligárquica) desplegaban cruentos enfrentamientos violentos que "desangran[ban] al país" (Acevedo 1994: 118).

Durante cincuenta años, después de la masacre de más de 30000 campesinos en 1932, el poder en El Salvador queda en manos de un gobierno militar basado en la represión y regido por un compromiso político entre los militares y la oligarquía. (Traducción mía) (Kaye 1997: 1). Estas circunstancias generaron la polarización de la sociedad y la inestabilidad política, hasta el punto de detonar la organización de grupos guerrilleros. Asimismo, la proliferación de la violencia militar y gubernamental aumentó y se volvieron constantes los ataques a los derechos humanos y civiles ejecutados por los llamados escuadrones de la muerte mediante sus "operaciones limpieza" (Kaye 1997: 696). Al respecto, Amnistía Internacional (1996) revela que:

\footnotetext{
los «escuadrones de la muerte» y los grupos paramilitares fueron responsables del asesinato secreto y sistemático, de la tortura y de la desaparición forzada de presuntos opositores políticos durante los años ochenta y principios de los noventa, pero gozaron de plena impunidad.
}

Después de constantes violaciones, conflictos y agresiones -matanzas, asesinatos, violaciones, torturas, desapariciones, rebeliones y manifestaciones sociales- finalmente surge la necesidad de fomentar la justicia y erradicar la impunidad a través de los Acuerdos de Paz y las llamadas Comisiones de la Verdad. Justamente, esta última se encargó de investigar las violaciones a los derechos humanos cometidos por las fuerzas del gobierno y la oposición armada y trató de reconciliar las agendas de diferentes sectores de la sociedad. (Traducción mía) (Kaye 1997: 698). Durante sus investigaciones, las Comisiones de la Verdad recibieron más de 22.000 denuncias de ejecuciones, desapariciones forzadas y tortura atribuidas al ejército y a grupos paramilitares ligados al estado y a los escuadrones de la muerte. El informe de dichas comisiones contempló tanto la condena internacional de las fuerzas armadas como la destitución de importantes figuras políticas y militares (Kaye 1997).

Aunque en la década del 90, los agentes involucrados en la guerra estaban dispersos y se habían convertido en grupos focalizados con manifestaciones aisladas, la violencia en El Salvador se intensificó y se manifestó de múltiples formas. Ana Arana (2001) afirma:

A pesar de grandes pretensiones, sin embargo, muy pocas mejoras [se han notado...] desde que las luchas cesaron [las repúblicas] en vez de exhibir las esperadas y nuevas manifestaciones de armonía y paz, solo cargan con las cicatrices y las heridas abiertas de sociedades traumatizadas: corrupción rampante, organización y ataques de pandillas, contrabando de drogas, pobreza urbana extrema y sobrepoblación, e indiferencia de la comunidad internacional. (Traducción mía) (88) 
De esta forma, a las manifestaciones sistemáticas de violencia estructural y cultural - gubernamental, militar, y guerrillera- se añaden otras más recientes, todas relacionadas con el capitalismo y los conflictos de clase apoyados por el autoritarismo estatal. Tal y como lo argumenta Giddens, el vínculo entre el estado moderno y el incremento escalonado de la violencia marcó los dos últimos siglos de la historia (Traducción mía) (1996: 3-27) y derivó, sistemáticamente, en desigualdad y exclusión.

Sumado a lo anterior, la adopción, en 1990, de un modelo socio-económico denominado la "ideología de la modernización"4 occidental configuró una subjetividad predominante y hegemónica basada en el neoliberalismo y el eurocentrismo. La implantación de este modelo repercutió en el aumento de las prácticas vinculadas a la exclusión identitaria. De igual modo, la modernización promovió la distancia entre burgueses y desposeídos e incrementó los índices de pobreza y exclusión social de minorías como mujeres, campesinos, obreros y trabajadores manufactureros y de la industria. Como parte de la modernización, se despliega la influencia de la industria cultural con la intención de homogenizar las poblaciones y neutralizar la diferencia. Alexandra Ortiz Wallner (200) apunta que el panorama presenta:

\footnotetext{
[una] agudeza de asimetrías sociales, económicas, culturales, frente a la insistencia de los sectores dominantes por instaurar un modelo de desarrollo que promete la inserción en el mercado mundial y la certeza por parte de los sectores populares y emergentes, de que este nuevo intento de modernización es la permanencia y vigencia del discurso de exclusión. (1)
}

El deseo de incorporar la región a un modelo de desarrollo económico globalizado favorece la instauración de una versión oficial de la imagen identitaria, producto de una cultura global, pero que deja excluida a una buena parte de la sociedad centroamericana puesto que esta no es un ente cohesivo sino, más bien, uno "diverso, plural y fragmentado" (Cortez 2002: 4).

La violencia representa claramente este tipo de exclusión, tal como la ilustra Nora Garita (2007) al afirmar que: "la nueva violencia aparece de manera progresiva conforme se separan los mundos de vida entre los que tienen de sobra y los que solo ven el callejón sin salida; [es] la concentración del ingreso la que genera abismos entre las oportunidades, polos de opulencia y exclusión" (18).

Un ejemplo más del esfuerzo por implantar el modelo de la ideología de la modernización lo presenta Beatriz Cortez (2002) al señalar que en El Salvador se intenta establecer un proyecto de identidad nacional basado en un sentido de pertenencia social y cultural, es decir, una conciencia que abarque rasgos identitarios comunes para todos los salvadoreños. Cortez apunta que dicho proyecto es sólo viable en la ficción, puesto que no existe una identidad común para todos, pues no se pueden regular las conductas ni homologar las formas de ver el mundo (1). En su opinión, si este proyecto unificador procediera estaría permeado por la exclusión y la violencia, ya que para ella la identidad es "personal, maleable y temporal" (Cortez 2002: 1).

Pese a la fuerte resistencia social, la instauración y la influencia de la ideología de la modernización y de los proyectos unificadores de identidad, el poder militar continuó; en consecuencia, la represión y la impunidad aumentaron, de la misma forma que surgieron nuevos tipos de manifestaciones de violencia cultural, como los delitos y los crímenes asociados al narcotráfico, las pandillas y la pobreza. Los integrantes de los sectores excluidos hallaron representación y reconocimiento solamente en el campo del arte y la estética. La literatura, por ejemplo, se convirtió en un espacio para denunciar y visibilizar la violencia, un sitio para representar sus identidades y subjetividades. 


\subsection{La literatura de posguerra y su relación con la violencia}

A pesar de que Werner Mackenbach (2004) polemiza la categorización de la literatura de posguerra al argumentar que no procede enmarcar a este tipo de literatura dentro del marco "posguerra" sino más bien dentro la clasificación de una literatura "posrevolucionaria"; la literatura publicada por algunos autores centroamericanos sigue las características temáticas de la literatura testimonial permeada, tanto por el desarrollo de los procesos militares-revolucionarios vividos en décadas anteriores como por el ordenamiento socio-económico establecido por la ideología de la modernización. La estética de esta literatura muestra la exclusión identitaria promovida por el sistema opresivo regido por el gobierno y los militares, donde una minoría es favorecida, mientras que la mayor parte del pueblo es relegado y no tiene acceso a la satisfacción de sus necesidades básicas inmediatas: agua limpia, comida, medicinas, educación y trabajo (Traducción mía) (Dickson-Gómez 2002).

Las imágenes visibles de la violencia presentes en los textos, provocadas por la guerra civil, resultan evidentes: asesinatos secretos y sistemáticos, torturas, desapariciones, violaciones, matanzas en masa, mutilaciones, destrucción, corrupción, drogas. Dickson-Gómez (2002) sostiene que la violencia colectiva no solo causa transformaciones en los perpetradores, sino también en sus víctimas y sus sociedades. Este tipo de violencia marca el cuerpo, la psique y el orden sociocultural (Traducción mía) (1). Según esta autora, las poblaciones marcadas por la guerra, sufren de PTSD (postraumatic stress disorder) y presentan efectos físicos y mentales manifestados en dolores de cabeza, nervios, falta de seguridad y confianza, y temor de ser objeto de violencia. Este desorden produce un trauma heredado trans-generacionalmente, es decir, las nuevas generaciones arrastran el desorden psicológico adolecido por sus progenitores y familiares y toda la población afectada cree que en cualquier momento puede ocurrir una agresión. Por esta razón, las víctimas viven con miedo, están a la defensiva y son propensas a la violencia porque es el modo que existe para defenderse. En consecuencia, la subjetividad está marcada por un alto grado de vulnerabilidad hacia un entorno que se presume adverso y que, por lo tanto, los sujetos y sujetas deben prevenir.

Los efectos postraumáticos, antes mencionados, se articulan discursivamente en los textos de posguerra, tanto a nivel referencial como simbólico. Así, en ellos encontramos imágenes que reproducen la violencia física y visible en formas diversas. Efectos no tan visibles, como los somáticos y psicológicos, aparecen representados a través de personajes trastornados por vicios, odios, rencores, deseos de venganza y locura. A menudo, los personajes de estos textos se apropian de la violencia como un mecanismo de resistencia contra la violencia a la cual se oponen. Nora Garita (2007) se refiere a la estética de la muerte y la violencia utilizada como un medio de denuncia: "los grupos avasallados se rebelaron contra los poderosos [hubo] movimientos que crearían una sociedad más justa, lo que planteaba la discusión sobre la legitimidad de la violencia en términos de medios y fines" (17).

Por otra parte, Beatriz Cortez (2000) afirma que la literatura testimonial de posguerra fue sustituida por la ficción caracterizada por la "estética del cinismo", una estética basada en la denuncia de los valores impuestos por las versiones oficiales de identidad e impulsada por la cultura popular de resistencia emergida de la naturaleza fragmentaria híbrida de la subjetividad. Dentro de ella, "el individuo aparece representado como un ser con necesidad de manipular [y] destruir su propio cuerpo para construir su subjetividad" (Cortez 2000: 1, 4). La relación de la literatura de posguerra con el cinismo, según Cortez, está enfocada en la crítica 
a la homogenización de la identidad. Esta postura se materializa mediante las representaciones del estado de caos, corrupción y violencia que afectan el contexto, principalmente, citadino y los procesos de construcción de las identidades.

Sheila Candelario (2004) asocia, metafóricamente, las representaciones textuales de violencia en El Salvador con la destrucción y la muerte, esta última se encuentra personificada y traducida en el avistamiento simbólico de "cadáveres" (sujetos) en el mundo cotidiano. Para Candelario, la violencia en El Salvador sigue un proceso cíclico-histórico y se mueve en medio de espacios que ocupan la hibridez que caracteriza su cultura:

\footnotetext{
estos espacios se bifurcan y entrecruzan en demarcaciones trazadas por culturas y lenguajes coexistentes [...] son espacios que dentro del trasmutar continuo de una historia en incesante movimiento hacia sí misma se nutren con constantes cuantificables en cientos de miles de cadáveres.
}

Es así como la recurrencia a imágenes vinculadas con la muerte, el caos social, el trauma de la guerra, las luchas sociales y la destrucción del cuerpo dan testimonio de la estética de la violencia en los textos de posguerra. Mediante dichas representaciones, los textos visibilizan la resistencia al poder militar, la denuncia de la opresión y la necesidad de una ruptura a la normatividad del caos social reinante debido a la desigualdad, la corrupción, exclusión y la impunidad. Los autores, mediante sus voces narrativas, se apropian y legitiman el uso de la estética de la violencia para evidenciar la precariedad de su cultura, y de esta forma, plasman una versión de la realidad y de la historia no-contada.

\subsection{Representaciones de la estética de la violencia en el testimonio y la ficción de posguerra}

Al inicio de la década de 1990, para estimular la expresión de quienes cohabitan en los espacios de exclusión, surgió el género del testimonio como práctica discursiva hegemónica, cuya función principal era la auto-representación del sujeto subalterno y marginado, es decir, del ‘otro' (Craft 2000: 81-82). El testimonio aparece dentro de la tradición literaria asociada a la cultura revolucionaria para favorecer directamente la expresión de aquellos sujetos implicados en la violencia de la guerra y la violencia militar-gubernamental de posguerra, rescatando las voces silenciadas, cuyas representaciones identitarias fueron omitidas por el discurso hegemónico con el afán de neutralizar la resistencia y afianzar a los grupos privilegiados en el poder. Según Craft (2000), poco a poco el testimonio empieza a 'novelearse' utilizando recursos de la ficción para comprometer la inmediatez y el efecto de lo real. La línea entre lo real y la ficción era cada vez más tenue.

Paulatinamente, la ficción centroamericana asociada al testimonio y a nuevas propuestas empieza a superar "el regionalismo y el realismo social prevalecientes anteriormente" (Acevedo 1994: 115). Luis Acevedo (1994) indica que los textos se valen de ciertos recursos: "el fluir de la conciencia, la fragmentación, la dislocación del tiempo, la multiplicidad de voces narrativas y la ambigüedad" (115) como características innovadoras de la narrativa.

En la ficción de posguerra, además de los recursos y dispositivos lingüísticos mencionados, se añaden otras técnicas que aportan valores importantes a las propuestas temáticas. Algunas de ellas son el exacerbado simbolismo colectivo, la figuratividad compleja, la deconstrucción, el estilo disruptivo de la narrativa convencional y la invención de personajes y subjetividades endémicas. Así, por ejemplo, la autora salvadoreña Claudia Hernández utiliza estos recursos en sus obras con el fin de abordar la violencia y reforzar sus propuestas 
temáticas. El fin vendría a ser robustecer la denuncia del estado de caos prevaleciente en la sociedad. Esta continua recurrencia enfatiza la crítica de la ideología dominante, al evidenciar la ruptura entre las políticas ejecutadas por el grupo político-militar salvadoreño en el poder y la hegemonía y otros sectores sociales.

Además, elementos del simbolismo y la figuratividad, técnicamente, crean múltiples imágenes e interpretaciones que -a su vez- magnifican los hechos violentos contados por la Historia. Tanto Argueta como Hernández han empleado en sus obras estas técnicas narrativas de formas muy distintas y, debido a ello, el análisis de sus obras no es de ninguna manera exhaustivo, es decir, puede abordarse desde muchas perspectivas y las interpretaciones que se extraigan variablemente dependerán de la negociación que haga el lector con sus textos.

\section{La desigualdad, la exclusión y los procesos revolucionarios en la narrativa de Manlio Argueta}

En los textos El valle de las hamacas (2008a) y Caperucita en la zona roja (2008) de Manlio Argueta ${ }^{5}$, aparecen representados de manera referencial los procesos históricoculturales que detonaron la inestabilidad política y el conflicto militar en El Salvador. A través de una clara referencia al proceso de la colonialidad, Argueta, de manera irónica, replantea la necesidad de visualizar los violentos orígenes de dicho proceso. Titula una de sus novelas El valle de las hamacas, nombre con el cual hace alusión al apodo que los colonizadores españoles le dieron al valle donde hoy se encuentra El Salvador (Browitt 2000). Sin duda, el título está teñido de una intencionalidad referencial discursiva al remitir directamente al contexto en el cual se gestaron las reacciones revolucionarias y los enfrentamientos con el gobierno militar. Los propósitos de evidenciar dichas realidades sugieren una denuncia de la descomposición social que vive el país, puesto que el autor está transmitiendo su conocimiento testimonial, matizado con ficción, de datos concretos y precisos de hechos violentos en ciertas ubicaciones espacio-temporales específicas.

Así, en la novela El valle de las hamacas se emplea la polifonía como un dispositivo de narración literaria. Es decir, desde diferentes perspectivas se narran algunos de los hechos histórico-revolucionarios en El Salvador y, de esta forma, se descentraliza la única voz existente, pues se establece un tono más objetivo. Por ejemplo, los personajes Ramón, Santiago, Fabricio, Tomasito y el Chatío constituyen voces de la resistencia, "las voces perdidas y silenciadas del pueblo" (Craft 2000). Sin embargo, también encontramos las voces de los académicos universitarios, quienes aportan sus apreciaciones de los hechos.

Otro recurso estilístico utilizado por Argueta en el desarrollo de la trama es la dislocación del tiempo y del espacio. Diversos pasajes fragmentados describen la experiencia de los personajes en pequeños relatos interrumpidos por diálogos, la inclusión de la voz del pensamiento en el fluir de la conciencia y la narración de los hechos realizada desde diferentes voces. Esta estructura narrativa le exige al lector reconstruir la historia a partir de diferentes voces, perspectivas, tiempos y escenarios.

Resulta pertinente mencionar que la fragmentación ${ }^{6}$ como recurso literario busca acabar con el relato totalizador que procura implantar una voz universal. De allí su afán por multiplicar las posibilidades de representación simbólica y referencial del 'otro' y por crear recursos de verosimilitud para 'objetivar' los hechos narrados. Para ilustrar lo anterior, El valle de las hamacas cuenta, primero, cómo los personajes están en medio de la selva tratando de 
sobrevivir en la misión de recuperar unas armas; seguidamente, el texto alude a la condición de otro personaje, Alejandro, herido en una celda y luego abandonado en condiciones salvajes en el bosque; finalmente, un pasaje narra, desde la voz de la conciencia de otro personaje, el contexto en el cual sucedió lo que había sido narrado anteriormente. A ello se suman, además, diálogos entre los personajes, los pequeños relatos del romance entre Rosaura y Raúl y las luchas sociales. Ahora bien, cuando los lectores continúan leyendo el texto descubren, en la segunda parte de la novela, que el personaje en la celda mencionado, en la primera parte de la novela, es Alejandro Rodríguez, quien es capturado y torturado por los militares corruptos.

El uso de esta estrategia narrativa genera en los lectores una sensación de desconexión e incoherencia, puesto que la atención se dispersa cuando se incorporan datos nuevos e inconexos. Mediante la desarticulación y la falta de coherencia en el estilo descriptivo, el escritor deconstruye la percepción lineal y homogénea de 'la' realidad y, propone -entonces- la complejidad, la heterogeneidad, la diferencia, la subalternidad.

En síntesis, la fragmentación persigue fortalecer la representación de la divergencia y evidenciar, asimismo, las disparidades en las representaciones identitarias. A través del estilo fragmentado, se muestra de qué modo se compone/articula el sistema social y se expone la dinámica de funcionamiento y su asociación al poder dentro de ese sistema entre los diferentes fragmentos. Algunos de ellos caracterizan la hegemonía y otros la subalternidad.

Por estos motivos, los dispositivos literarios utilizados en El valle de las Hamacas sugieren una propuesta discursiva contestaria opuesta a la descomposición social y a la violencia generada por la hegemonía militar y el autoritarismo derivados de la ideología de la modernización. La descripción de esta situación en la novela y de otras entrelazadas, pero ubicadas en diferentes partes del texto, las encontramos a través del personaje de Raúl, un estudiante universitario, quien mediante la voz de su conciencia, describe la precaria situación política de su país desde la perspectiva de los revolucionarios en El Salvador:

Y es que en este país todo va envuelto en, politiquería y en política el vaho del trópico no sólo está envuelto
en bolas de aire seco y caliente sino en nubes de hedor una tormenta cotidiana y uno dando saltos para no
caer y llenarse todo y después morir como micos oliéndose el dedo sin comer ni beber. (Argueta 2008a: 32)

En el fragmento anterior, pese a su condición de estudiante universitario, Raúl constituye un personaje marginado que, figurativamente, vive en medio del hedor producido por las tormentas cotidianas. Se puede interpretar que las nubes simbolizan no solo la atmósfera que envuelve el entorno sino también las políticas que descienden en forma de lluvia torrencial, que producen el mal olor, y que impiden visibilizar claramente la realidad. Metafóricamente, la narración hace alusión a la caída de excremento (de la misma forma en que lo hace Hernández en Lluvia de trópico). En este sentido, la sensación de que el entorno hiede a excremento evoca la frase "no llenarse todo" y el narrador, aunque está tratando de esquivar la pobreza, el hambre y la precariedad, tiene la certeza de que está irremediablemente destinado a morir en medio de él.

Además observamos la forma como Raúl problematiza y critica la situación sociopolítica de su país:

[...] y así quién va a querer hacerles competencia a estos cabrones [los pájaros que usan uniformes militares cosidos con hilo de oro] esa es la historia del país mientras los diferentes cuelgan de los árboles amenazados por los zopilotes en las montañas no sin haberles sacado la masa encefálica [...] así pasa con aquellos que tratan de cambiar la atmósfera cargada de hedor. (Argueta 2008a: 33)

Aquí, además de mostrar la polarización entre la clase gobernante y los sectores populares como los campesinos y los insurgentes -por un lado están los “cabrones” pájaros 
de uniforme de oro y por otro los "diferentes" colgados de los árboles-, evidencia también la desigualdad de clases: por un lado, la política integrada por militares, burguesía y gobierno (los zopilotes) y por otro lado, los perseguidos por los "zopilotes", los 'otros', los "diferentes", al intentar cambiar su entorno y al oponerse al "estado inhumano" en el cual viven o se convirtieron en cadáveres, puesto que les sacaron su masa encefálica o los dejaron como seres inhabilitados mentalmente. La mezcla de figuratividad y realidad en la articulación de la voz de la conciencia de Raúl permite al lector visualizar la descomposición, la exclusión y la violencia en el contexto salvadoreño desde la perspectiva de los excluidos.

En este mismo sentido, también encontramos evidencias de descomposición social a través de la voz de Alejandro, otro revolucionario, quien describe la lucha y la tortura del subalterno al confrontar a los militares:

\begin{abstract}
Se retorcía en la viga queriendo esquivar la hoja del cuchillo. Por mi madre que no tengo nada... por favor... ipor favor! El joven del cortaplumas afirmó la hoja filosa con el dedo índice y el pulgar haciendo salir apenas la punta del arma. [...] se abalanzó contra su presa; la navaja le penetró hasta el fondo. El colgado sólo emitió una especie de rumor o último suspiro. (Argueta 2008a: 89-90)
\end{abstract}

El narrador también recurre a la voz femenina para ilustrar el conflicto revolucionario desde la perspectiva de la clase académica. Así, la esposa del decano critica la violencia utilizada por la Policía Nacional para representar el autoritarismo:

\begin{abstract}
[...] era terrible ver cómo un grupo de muchachos de veinte a veinticinco, con las manos en alto decían 'piedad ya no nos peguen somos humanos, déjennos ya' y caían, y caían, y siempre les decían 'aquí están sus cuilios, ya ven pegan duro, sus chuchos, como ustedes nos llaman, tal vez así dejen tranquilo al pueblo, comunistas'. (Argueta 2008a: 57)
\end{abstract}

El fragmento anterior relata el enfrentamiento entre universitarios y militares, en donde estos últimos irrumpieron violentamente dando garrotazos a quienes se encontraban a su paso en la universidad, tomaron a las mujeres y luego se las llevaron para encerrarlas en un vehículo: "al llegar las metieron a un cuarto y ahí el cuadro era aterrador: muchachos tirados en el suelo y bañados en su sangre" (Argueta 2008: 68). Ante esta situación, el narrador se pregunta hasta cuándo los militares van a estar sumidos en "la ignominia incultura cinismo cobardía hoy matan a uno mañana a otro y te tiran al río en sacos de yute y te encuentran desfigurado el rostro como un crimen más no se averigua nada" (Argueta 2008: 71).

De forma similar, la clase académica representada en el personaje del "decanito", presenta la situación desde una perspectiva más reflexiva, abordando la situación social desde una racionalidad académica pero, a la vez, de una forma mucho más pasiva. Él está convencido de que a todos los centroamericanos les tocó vivir en "el culo del mundo y esa es una situación a perpetuidad" (Argueta 2008: 81). El "decanito" utiliza el diálogo con el propósito de que su discurso contraste con el discurso revolucionario y violento de Raúl:

[...] pero no me vas a convencer que no llevas, en tu conciencia el germen del suicidio, de la autodestrucción, es una especie de cobardía elevada a categoría de valor. Porque no me vas a convencer que con cuatro fusilitos vas a construir un nuevo mundo, en esta península empantanada que es Centroamérica. Ustedes pierden la perspectiva, por fuerza de la realidad es precisamente que se darán los cambios, cuando los países civilizados hayan cambiado; dejemos que ellos tomen la iniciativa [...] por qué nosotros los insignificantes, los plataneros, los cafetaleros [...]. (Argueta 2008a: 30)

El decano personifica a la clase media que en medio de su confort e indiferencia invalida y deslegitima la lucha revolucionaria en contra de la exclusión y la injusticia social. De alguna forma, él aborda la situación de su país desde su perspectiva academicista valiéndose, 
según su criterio, del poder de los recursos discursivos para lograr cambios sociales más que de recursos armamentistas. El cambio vendrá a través de las iniciativas que tomen los "países civilizados" y no a través de los insurgentes pobres o "insignificantes".

Asimismo, otros pasajes narran reflexiones sobre la lucha, o bien, describen las confrontaciones entre los revolucionarios y los militares. En dichas descripciones, el lector puede descubrir que los rebeldes utilizan los elementos que tienen a su disposición para defenderse; así, mientras los militares descargan gases y balas, ellos utilizan naranjas. Los hechos evidencian la notable desventaja para los insurgentes en el conflicto y se transluce la sugerencia de que la lucha, irremediablemente, es un fracaso.

De un modo directo, las citas anteriores ilustran el estado de caos, la descomposición social y la violencia física empleada por los militares para controlar la población, al mismo tiempo que buscan interpelar al lector al presentarle situaciones opresivas en contra de quienes están fuera del poder.

Finalmente, en la última parte del texto se sugiere que la violencia, representada en las luchas y en las grandes brechas sociales, tiene como origen el legado heredado por los procesos de colonización y colonialidad. En medio de un viaje por la antigua ciudad de El Salvador, el narrador parodia utilizando la manifiesta:

Yo te consagro ciudad hija de Dios muy noble y leal a la corona, esclava fiel, siervo que encenderá todas las teas que necesita el amo para no tropezar, te consagro dadora de tu misma sangre, ingenua porque crees en todo lo que digo; porque mi palabra es el espejo donde te miras, [...] te consagro a vivir plenamente como mereces, a no aspirar, a no levantar la mano, a no hablar mientras yo hablo, a no sonreír, sino cuando te lo ordeno, si así lo hiciereis que la corona os premie, sino que os demande. (Argueta 2008a: 128)

Al emplear la primera persona, el narrador -mediante la consagración- condena a su país a vivir en la esclavitud, la ingenuidad y la dependencia, elementos que pueden potencialmente garantizar una decadencia social sistemática y constante, puesto que prevalecerá el status quo, en donde, la violencia de la exclusión seguirá predominando, y por ende, seguirán acrecentándose los conflictos en medio de la impunidad. A lo anterior, se suma la condición de que "desde el primer contacto con la civilización estuvimos en desventaja, emprendimos una guerra desigual: hombres contra dioses" (Argueta 2008a: 132). Esta voz sugiere que, siguiendo el ejemplo de los españoles, los gobernantes y la clase en el poder se han convertido en dioses, pues viven a su antojo, controlan al resto de la sociedad, gozan de total impunidad y doblegan con violencia a quienes se atrevan a oponérseles. Estas condiciones heredadas mantienen a la sociedad salvadoreña dividida en muchos sectores excluidos y subyugados. Desde entonces, para el pueblo subyugado -constituido por trabajadores, campesinos, mujeres y pobres- no ha habido salida porque no han tenido el derecho de aspirar ni de alzar sus manos y han debido callar y recibir órdenes de los "dioses" de la clase política en el poder.

La yuxtaposición de la situación socio-política salvadoreña y el proceso de la colonización española -la colonialidad propuesta por Mignolo (2005)- muestra con claridad que la violencia de la exclusión tuvo su raíz dentro de "una lógica encubierta que impone el control, la dominación y la explotación, una lógica oculta tras el discurso [del] progreso, la modernización y el bien común" (Mignolo 2005: 32). Este presupuesto es sostenido y ampliado por Cortez (2002) cuando ella cuestiona las intenciones del gobierno salvadoreño de implantar un proyecto de identidad nacional homogeneizador. Según esta autora, en este proyecto, los gobernantes y grupos en el poder, al no reconocer la diferencia, establecen un mecanismo generador de violencia de exclusión y motivan la organización de grupos de resistencia y liberación, puesto que, al existir un proyecto político generador de una identidad predominante, 
regulada, común, y fija, dentro del mismo sistema, brotarán las contradicciones y, por ende, la resistencia que estimulará la creación de grupos conformados por las identidades fragmentadas que no se ajustan, que son cambiantes y que se resisten contestariamente a la fijación.

En este sentido, El valle de las hamacas responde contestatariamente, al apropiarse de la violencia, contra la versión oficial (hegemónica) de la historia de El Salvador y la reinterpreta, al concederle resonancia a las voces silenciadas por la historia (Craft 2000: 82). No obstante, pese al empleo de recursos literarios y temáticos, la novela parece mantener un tono de resignación que le resta fuerza a la lucha por el reposicionamiento social del 'otro'. De acuerdo con el texto, surgen interrogantes relacionadas a la sociología, como por ejemplo, ¿estarán -irremediablemente- los salvadoreños destinados a experimentar la opresión ejercida por la clase política y militar?, ¿serán insuficientes e inefectivos los intentos de cambiar la realidad las políticas excluyentes?, ¿estarán los grupos revolucionarios siempre en desventaja? ¿Prevalecerá la injusticia y la impunidad? Al menos, puedo confesar que el utilizar la literatura como medio de denuncia social ha contribuido a hacerme consciente de realidades ajenas.

\subsection{La influencia neoliberal y la exclusión en Argueta}

En otra novela de Argueta, Caperucita en la zona roja, se aborda la temática asociada a la descomposición social en su país, las formas de resistencia, los movimientos revolucionarios, las luchas bélicas y la exclusión del pueblo salvadoreño. En ella, se utilizan algunas estrategias literarias presentes en El valle de las hamacas. Por ejemplo, se recurre a la polifonía, se representa - mayormente- la diversidad de contextos y los intertextos para articular la historia. El propósito de emplear dichos recursos es contrastar-concienzudamentela cultura autóctona y la influencia de agentes externos que han propiciado el surgimiento de una "incipiente sociedad de consumo en su versión centroamericana" (Muslip 2008). El texto parece criticar los efectos de la ideología de la modernización en El Salvador al evidenciar, en forma irónica, la presencia de productos importados (cerveza, por ejemplo) en el seno del grupo revolucionario que está buscando su inserción social. Además, la referencia a canciones populares, refranes, cuentos infantiles y otros tipos de expresiones populares sugiere la exposición de los personajes, en la novela, que viven en los bordes fronterizos (Muslip 2008) representados por lo urbano y lo rural, los ricos, los pobres y los que están en el medio, así como los que cohabitan en los límites que demarcan la supervivencia y la muerte.

La novela, a través del personaje de Alfonso, formula los conflictos internos que sufre un poeta revolucionario que se debate entre el compromiso con la lucha social de su país y su romance con su prima Hormiga. En primer lugar, la zona roja representa la zona de conflicto en donde se evidencia la lucha social. Desde allí, un grupo pequeño de personajes trabajan, de manera clandestina, en una imprenta para la insurgencia. Se encargan de la divulgación de los objetivos de la lucha.

En adición, el personaje Manuel intenta "articular los intereses de los sectores burgueses [principalmente académicos] de ideología de izquierda con la necesidad de mostrar políticas de interés para los sectores populares" (Muslip 2008). De tal modo, la novela recrea la tensión existente entre la cúpula de poder -la alianza entre el gobierno, los militares y los burgueses- y los sectores excluidos. Este último grupo, debido a la opresión y a la dominación, reacciona violentamente contra el sistema. Por ejemplo, el papá de Alfonso recibió un balazo cuando intervino en un levantamiento para ir a saquear las casas de los ricos que tenían acaparado el maíz (Argueta 2008b: 33) ${ }^{7}$. 
Por otra parte, en forma simbólica, la novela recrea -desde el título de la obra- el cuento original de Caperucita Roja. Juan Charrasqueado, representante de la autoridad o de los militares, acosa a una niña Caperucita, representante de la sociedad indefensa, y Juan, por ser ignorado por ella, desenfunda una ametralladora en contra de la abuelita y la mata (Argueta 2008b: 55). Simbólicamente, el hecho constituye una clara manifestación de la violencia, la prepotencia y el autoritarismo por parte de los militares hacia los desvalidos, un hecho que quedará en la impunidad. También, a manera de testimonio, se narra la manifestación estudiantil en el Hospital de Niños, en donde se relata la persecución, la tortura y la violencia que predominó en el conflicto,

\footnotetext{
cuando llegamos al Seguro Social vi un montón de cabezas corriendo y más atrás, en el paso a dos niveles, avanzaban los tanques con las luces encendidas [...] mataron a los compañeros que iban adelante con los micrófonos y banderas, fueron los primeros en caer [...] murieron quince estudiantes, mujeres entre ellos. (Argueta 2008b: 120-122)
}

Además, en el texto, aparece la referencia al asesinato de Monseñor Romero ocurrida el 24 de marzo de 1980, cuando Monseñor Aparicio da un discurso, no se sabe si fue una homilía o una postulación para lograr un puesto en la iglesia. Critica abiertamente la "interminable cadena de abusos e injusticias" (Argueta 2008b: 163), sufridas por las clases menos privilegiadas y ejercidas por parte de "una oficina" en complicidad con la prensa. Cuestiona, a su vez, a los académicos salidos de las aulas, quienes una vez en el poder, "se prestan como miembros del poder judicial, a las ilegalidades, injusticias y atropellos y fatídicos cuartelazos" (Argueta 2008b: 164).

Por último, el texto muestra la voz del presidente del país al ofrecer un discurso al cuerpo diplomático. Sus palabras reproducen y reafirman las políticas excluyentes y discriminatorias del gobierno: primero, se deja claro la alianza del gobierno con los "cafetaleros, algodoneros y dueños de industrias" quienes son los responsables de enriquecer al país; luego, la posición de los excluidos en esta fórmula, "el que nació pobre, que siga pobre [...] esa es la ley universal" (Argueta 2008b: 168). Aquí, el presidente ofrece un ejemplo de intertexto al aludir el discurso bíblico que manifiesta que siempre habrá pobres entre el pueblo y, desafortunadamente, la intención política de legitimar y perpetuar las condiciones de precariedad en que viven los pobres. El presidente esencializa la condición de pobreza.

La lucha en la novela termina en derrota, y por ello, la propuesta final sugiere que los esfuerzos de cambio fueron en vano. Las consecuencias son la descomposición social, la proliferación de la violencia y la injusticia. Aunque Argueta ilustra referencialmente la historia bélica-revolucionaria que ha vivido la sociedad salvadoreña y la violencia consecuente, el impacto del texto no es tan evocativo como los textos de Claudia Hernández, en el sentido de que el estilo de Hernández se distancia -definitivamente- del discurso referencial y, en contraste, ofrece textos con un alto nivel simbólico y con una marcada riqueza en el uso de la connotación. Esta característica resulta ser altamente provocativa, ya que fomenta respuestas más imaginativas a la violencia.

\section{Claudia Hernández y la estética de la violencia: El realismo grotesco bajtiano, deconstrucción, y esquizofrenia}

En sus libros De Fronteras (2007) y Olvida Uno (2005), Claudia Hernández ${ }^{8}$ describe, $^{2}$ en una serie de cuentos cortísimos, el agobio que sufren los sujetos al habitar los bordes fronterizos geopolíticos, simbólicos e imaginarios. Ellos coexisten justamente allí donde los 
límites de lo que se presume como normalidad, en donde los valores y principios que dictan la normatividad, no están claramente demarcados y se ven expuestos al desorden y la anarquía que a menudo degenera en violencia. Sin límites (borders) definidos, no existen divisiones que separen la normalidad de la anormalidad, la racionalidad de la locura, la realidad de la fantasía, lo real de lo inverosímil y la normatividad de la transgresión. A diferencia de Argueta, los textos de Hernández delinean la subjetividad desde una perspectiva anómala de la realidad y desde la transgresión. Transgrediendo dichos límites, Hernández explota simbólicamente las representaciones de sus personajes y de sus escenarios construyendo tramas que ambiguamente pueden correlacionarse con la subjetividad, el contexto y los conflictos sociales salvadoreños.

Las representaciones de Hernández sugieren una ejemplificación de la risa ritual y del realismo grotesco extraída de la obra de Mijaíl Bajtín (1995) en su crítica al texto literario de Rabelais ${ }^{9}$. La esencia de la risa ritual señalada por Bajtín (1995: 20) es la ambivalencia que se destaca entre el humor satírico, la burla y el escarnio y la provocación del humor, características que Hernández utiliza cuando parodia, satiriza y caricaturiza a sus personajes con el fin de escarnecerlos (Bajtín asocia estas manifestaciones con el escarnecimiento al régimen feudal y a la iglesia). También resulta aceptable, además de la risa ritual, vincular la concepción estética bajtiana del realismo grotesco a las representaciones utilizadas por Hernández cuyas características fundamentales están asociadas a imágenes relacionadas con la degradación- a la "transferencia al plano material y corporal de lo elevado, espiritual, ideal y abstracto" (Bajtín 1995: 23, 24). Las imágenes grotescas aludidas por Bajtín (1995: 23, 24) parecen deformes, monstruosas, horribles y están inmersas dentro de un marcado hiperbolismo de imágenes materiales y corporales y de exageraciones que tienden a tener un sentido positivo y a la vez contemplan un principio regenerador. La utilización de dichas imágenes tiene como único fin el degradar, corporizar y vulgarizar.

Las representaciones grotescas aparecen en los textos de Hernández a través de la descripción de monstruosidades simbólicas (especies endémicas, hombres mitad humanos mitad animales, hombres mutilados y deformes) inmersos en ambientes imbuidos de fluidos y olores corporales como la caca, orines, sangre y basura, representaciones que bien pueden asociarse simbólicamente a subjetividades fronterizas marginales. No obstante, a los personajes representados, la narración les adscribe estilos de vida connotativamente positivos (estrategia que yo además asocio a la deconstrucción) con el fin, no solo de evocar en el lector una reacción satíricamente humorística, sino también de evidenciar la necesidad de promover cambios sociales. El rebajamiento y la degradación características de la imagen grotesca comprenden un sentido positivo y regenerador propio, según Bajtín (1995: 86-116), de épocas de mutación y de mundos incompletos y en proceso de transformación con un pasado de descomposición y un porvenir en vías de formación.

Ahora bien, debido al carácter simbólico del lenguaje, al uso de la parodia, la caricatura y la sátira, el lector está obligado a recrear y a reconstruir la trama de un modo imaginativo que le permita negociar sus interpretaciones con el texto, muy a pesar de las diferencias que surjan debido al historial del lector mismo, de la influencia del autor y de las realidades del contexto en que se desarrolla la obra, entre otros factores.

Hernández además utiliza la deconstrucción ${ }^{10}$ como un recurso para posicionar, irónicamente, los estados de degradación, rebajamiento, y de negación en estados de seguridad, estabilidad, bienestar, felicidad y progreso social. Para lograr esto, las representaciones resaltan que alrededor de la degradación se articulan otros elementos, como el aislamiento, la destrucción, 
la corrupción, la violencia y la predisposición a la muerte, que constituyen la plataforma del estado de normalidad. De este modo, mediante sus representaciones, Hernández enmarca las características de la subjetividad salvadoreña.

Irónicamente, al establecer estos estados de insuficiencia en los textos como los estados óptimos de estabilidad y confort que los sujetos y sujetas parecen disfrutar, la narración deconstruye la noción de normalidad; puesto que el orden reinante a mantener es precisamente el caos, la degradación y la violencia.

Satíricamente, a través de la deconstrucción, los textos sugieren que dichos estados enmarcan la noción de "progreso" en la sociedad salvadoreña, estados que Sheila Candelario (2004) describe como "avances tecnológicos dispares, neo-liberalismo excluyente y polarizante, estragos económicos de guerras aún presentes en el plano político tergiversado”. Estas condiciones han llegado a establecer la normatividad que fundamenta la vida cotidiana, una vida enmarcada por la precariedad y aparentemente dirigida a la degradación social: los sectores menos privilegiados continuarán excluidos y empobrecidos, la violencia caracterizará la cotidianidad y la impunidad prevalecerá entre los corruptos, entre muchas otras condiciones más.

De acuerdo con lo anterior, los textos de Hernández pueden asociarse con una estética que representa la descomposición social y la violencia, y que van más allá de la estética del cinismo planteada por Cortez (2000) al referirse a la literatura de posguerra. Específicamente, el planteamiento de Cortez describe el cinismo como el rompimiento de la normatividad en el ámbito privado. Allí, los sujetos intentan destruir sus propios cuerpos para construir su subjetividad, puesto que al autodestruirse, ellos pueden expresar su necesidad de manipular y de ser aceptados por la sociedad, pero siempre dentro de un mundo de libertades ficticias, ya que fuera del espacio propio prevalece el caos, la corrupción y la violencia como modo de vida y de sobrevivencia (Cortez 200: 2).

Sin embargo, la estética de la violencia utilizada por Hernández recurre al cinismo y lo trasciende, no solo por la trasgresión de los personajes en sus espacios internos y privados, sino también por las constantes irrupciones y agresiones que experimentan ellos en los espacios externos (Candelario 2004). Por ejemplo, los estados escatológicos de descomposición personal y social que caracterizan la subjetividad, la degradación excesiva, la locura y la transgresión proyectan el enrumbe directo hacia la agonía, la extinción y la muerte. Ahora bien, conviene resaltar que, en los textos de Hernández, estos estados son presentados como estados de satisfacción, ventura y fortuna. Es decir, se trata de una esquizofrenia, vinculada con la literatura ${ }^{11}$, dentro de un imaginario caracterizado por la fantasía e irrealidad, en un nivel simbólico dentro de un inconsciente colectivo mítico.

La relación simbólica entre los estados esquizofrénicos y la construcción de las subjetividades se convierte en un recurso para deconstruir el logocentrismo presente en la idea totalizante de la subjetividad hegemónica occidental impuesta por las autoridades en El Salvador e implantada por la influencia de la ideología de la modernización. En otras palabras, la esquizofrenia pretende desconfigurar los proyectos neoliberales de construcción de identidad homogénea, al mismo tiempo que busca desestabilizar la noción de una identidad nacional que deja de lado la hibridez de las culturas (Cortez 2002).

La representación de subjetividades esquizofrénicas no solo plantea una subversión deconstructiva que procura revertir la posición de las subjetividades: las presentes/privilegiadas/ hegemónicas (constituidas por el estado-oligarquía) por las ausentes/excluidas/no privilegiadas (las clases populares, los indios, campesinos). También pretende mostrar identidades diferentes y demandar reconocimiento social. 


\subsection{La dislocación del tiempo y del espacio: La presencia de personajes desarraigados y aislados}

La deconstrucción y las técnicas literarias utilizadas por Hernández refuerzan sus propuestas temáticas. Como Argueta, ella también utiliza la polifonía mediante la inclusión de las voces de una diversidad de personajes, pero las voces narrativas de Hernández no son siempre racionales o coherentes, sino que, en algunos casos, son voces fantasiosas que parodian y/o simbolizan a algún agente social. En muchos casos, la autora presenta a estos personajes como sujetos incapaces de organizar, racionalmente, su pasado y futuro. Más aún, la vida de algunos de ellos constituye un cúmulo de fragmentos aislados. Además, sus experiencias son trozos contingentes de lo heterogéneo, lo fragmentario y lo aleatorio, similar a los personajes esquizofrénicos en literatura, según Jameson (2007). Dichos personajes, además, aparecen dislocados en el tiempo, es decir, se ubican en diferentes tiempos y escenarios en medio de una variedad de conflictos, de ahí que con frecuencia encontremos disrupciones en la trama que combinan flashbacks, flashforwards y retornos al presente.

Para ilustrar, la caracterización de los personajes centrales en el cuento Un hombre desnudo en casa nos refiere a un hombre y una mujer perdidos en el tiempo. En primer lugar, la narración se hace desde el presente cuando un hombre desnudo aparece, de repente, en la casa de una mujer, quien sin conocerlo, le está preparando café. Al interrogarlo para conocer sobre su proveniencia y su pasado, contesta: “[...] ¿Que dirías si me preguntan quién sos? —Di 'No sé de dónde salió'- 'Claro - contestarán- Asegura no conocerlo, pero lo tenía en su casa desnudo y bebiendo café con usted’ (Hernández 2007: 29-30). Después de un mes de convivencia, continúan sin conocerse y la única posibilidad de cambio en el futuro lo representa la muerte: "Si prefieres, puedo morirme en otra parte. - Daría lo mismo: en tu piel o en tu mirada estaría escrito que comenzaste a morir acá" (Hernández 2007: 30). La evidencia del desarraigo, encarnada por su misma desnudez (no usa ropa ni ningún tipo de artefacto que cubra su cuerpo y que denote su filiación cultural), más la evidente incapacidad que muestra de reconocer su pasado y su presente remiten al sujeto aislado, perdido en el tiempo y en el espacio, excluido del entorno social, carente de una conciencia de realidad que él mismo se niega a hallar, pero que, no obstante "ríe" como burlándose de sí mismo (Hernández 2007: 30).

A través de la desnudez y el aislamiento, se evidencia la descomposición emocional del sujeto y el deterioro del entorno. Afuera lo espera la muerte: "con terror y tristeza [y] salió por la ventana. No he vuelto a verlo" (Hernández 2007: 29). No obstante, cabe resaltar que los dos personajes de este cuento se encuentran muy cómodos con su condición; por ello, todo trascurre con normalidad. El desarraigo, el aislamiento y la espera de la muerte son las condiciones de la vida.

En esta misma línea, el cuento Trampa para cucarachas deconstruye también la idea de bienestar y de felicidad al presentar un personaje sin raíces, aislado y solitario en la ciudad, donde su único contacto con el mundo exterior es el administrador excéntrico de la pocilga en donde vive y una plaga de cucarachas que lo invade. Sin trabajo y con hambre, este hombre se aboca a tratar de erradicar las cucarachas de su cuarto y, después de muchos intentos y tras sentirse vencido por estos animales, decide abrir su boca y comérselas:

Todo me había fallado [...] las dieciséis trampas [...] No acudieron a comer las migas de pan [...] Ignoraron las bolitas de veneno [...] No le prestaron atención al plato de comida [...] no pusieron una pata encima de mi ropa cuando le regué veneno para que cuando se asentaran se contaminaran [...] Nada funcionó [... hasta que] yo haciéndome pasar por muerto, era el mejor cebo. Dejaba de respirar y ellas me recorrían confiadas hasta entrar en mi boca abierta, con la que las atrapaba. (Hernández 2007: 82) 
Esta "hazaña" se traduce en un doble triunfo: mata su hambre y mata a las cucarachas. El comerse las cucarachas le permite experimentar la felicidad que buscaba en la ciudad donde, según él, iba a conseguir un trabajo, iba a socializar e iba a llevar una vida "normal". Su acción -metafóricamente- reivindica su condición de sujeto y lo hace sentir como un vencedor dentro de su miserable existencia, caracterizada por la carencia. Tanto las acciones del personaje como el ambiente en donde se desarrollan evidencian las imágenes grotescas en donde el cuerpo es mostrado como un agente expuesto a la degradación, en un acto culturalmente inaceptable, cuando el personaje consume cucarachas.

El bienestar está circunscrito a condiciones degradantes, conflictivas e incluso autodestructivas, tanto en el espacio interno -la casa de la mujer en Un hombre desnudo en casa-, como a nivel externo -la ciudad en Trampa para cucarachas-. La felicidad está supeditada a estados de descuido, soledad, angustia e impotencia. Los personajes de ambos relatos connotativamente retratan su condición de excluidos y sus condiciones de vida ilustran la opresión que enmarca su 'modus vivendi'.

Estas condiciones se presentan, una vez más, en el cuento Mediodía de frontera, pero en este caso, se asocian directamente a la muerte. En ese relato, encontramos a una mujer que decide cortarse la lengua antes de ahorcarse para que ésta no esté afuera cuando ella muera. Antes de hacerlo, ella conversa con un perro abigarrado y flaco que lame la orina del baño de los hombres en donde ella va a acabar con su vida. Finalmente, la mujer se suicida y el perro se come la lengua que ella misma ha partido en pedazos. En esta historia, podemos visualizar cómo el sujeto se mutila y se autodestruye; la fragmentación de su cuerpo le permite cruzar la frontera entre la vida y la muerte en un acto circunscrito a un escenario escatológico: el baño de hombres, ocupado por un perro que chupa orines, que a la vez le provee a la protagonista el ambiente ideal para ejecutar su muerte, una muerte que estéticamente merezca la aprobación de quienes la encuentren; de hecho, ella también cose su boca para que no caiga una vez muerta. Al autodestruirse, se encuentra con la felicidad puesto que se convertirá en "una ahorcada feliz" (Hernández 2007: 102). La felicidad, en este caso, está asociada al desmembramiento y al suicidio, y la belleza a lo chocante y burlesco, elementos que constituyen una estética autorial particular. Una vez más, la narración incurre a la degradación de imágenes con el fin de parodiar.

Por último, cabe indicar que estos textos comparten la característica de presentar personajes incapaces de reconocerse en su propio espacio y en el espacio del 'otro' debido al desarraigo y al aislamiento. Deconstructivamente, estas condiciones enaltecen sus vidas, la precariedad distingue a los personajes y los honra, al punto de que ellos consideran que han alcanzado la felicidad y el bienestar.

\subsection{Los delirantes, alucinantes y locos}

Otra técnica literaria ligada a la representación de personajes esquizofrénicos es el fluir de la consciencia, un modo de articulación del pensamiento inconsciente que, en los textos, resulta ser una forma incoherente de comunicación interpersonal. Por este motivo, la ruptura de expresiones en la comunicación y la falta de lógica en el hilo conductor de algunos relatos se asocian con personajes poco racionales, esquizofrénicos.

En algunos diálogos, se observa que la relación entre signo y significante conlleva la pérdida de lógica en el significado. El resultado es una amalgama de significantes, sin correlación, lo cual se traduce -en consecuencia- tanto para el personaje como para 
los lectores, en la sensación de pérdida de control y de coherencia. El personaje aparece desestabilizado y desconectado de la realidad, razones por las cuales delira y alucina en su afán por controlar la percepción. Paradójicamente, estos personajes no solo encuentran estabilidad en la incoherencia que, de manera simbólica, podría representar el contexto caótico en el cual habitan (la sociedad) sino que también provocan una risa burlona e irónica en el lector.

Específicamente, en el texto Molestias de tener un rinoceronte, al personaje principal, un joven sin brazo, lo persigue un rinoceronte, mas el texto sugiere -al mismo tiempo- que éste no existe:

Uno [...] tiene que andar por las calles soportando que la gente lo mire, le sonría y hasta platicar de lo lindo que está su rinoceronte, señor, no lo compró acá, ¿verdad? ¿De qué rinoceronte me habla, señora? Del suyo, por supuesto. Disculpe, se equivoca [...] les aseguro mientras me aseguro de que estén viéndolo a él y no a mi brazo que no está. (Hernández 2007: 11)

Esto resulta ambiguo: ¿está o no está el rinoceronte?, ¿está el rinoceronte sustituyendo simbólicamente al brazo del personaje?, o quizás, ¿sufre el personaje de delirio o alucinaciones? Al lado de estas interrogantes, el texto plantea que el animal lo sigue desde el día que perdió su brazo. Tanto para el lector como para el personaje, el rinoceronte es un animal pacífico que solamente reacciona de manera agresiva si se le provoca; ahora bien, este animal también puede simbolizar el brazo perdido. Si consideramos lo anterior, el rinoceronte viene a formar parte de un violento desmembramiento y desgarramiento del cuerpo y, por eso, es también el recuerdo cotidiano de su mutilación. Sin embargo, el rinoceronte, aunque significa un problema para el hombre, llega a ser el amigo, el compañero de vida. Realidad o fantasía, el rinoceronte en sí mismo ofrece representaciones simbólicas de los estados internos y externos de un personaje solitario y mutilado por su realidad.

En Un demonio de segunda mano, la situación del narrador-protagonista es similar a la del personaje del cuento analizado antes, pues el narrador observa a un ser, pero no puede determinar si éste es hombre, demonio o fantasma. Lo único que sabe es que es lamido por los perros cuando estaba sentado a la par de recipientes de basura y que se encontraba "solo [...] desnudo y viejo, y amordazado y atado de pies y manos, y sin ojos" (Hernández 2007: 87).

Más adelante, el protagonista -que posee intenciones de establecer una relación amorosa homosexual- invita a aquel ser a vivir con él, pese a que el invitado reiterativamente le menciona que es un demonio que lo conoce desde antes. Después de un tiempo, el demonio y su anfitrión adquieren confianza uno con el otro, mas siempre impera la duda de la naturaleza del primero: "El me embelesaba con el relato de historias milenarias que yo creía inventadas aunque él insistiera en que eran fruto de sus experiencias como demonio" (Hernández 2007: 92). Poco a poco, el demonio va tomando el control de la vida de su amigo, pero al regalarle este último un par de ojos grises, el demonio sale del aislamiento de la casa y empieza a socializar con otras personas. El amigo siente su abandono y se enfurece y, después de una fuerte pelea, el hospedador termina en la condición en la cual halló al demonio: sin ojos, desvalido, abandonado, sucio, atado y en medio de la basura.

Aunque los hechos en la trama de este relato poseen una secuencia lógica, la presencia ambigua del demonio obliga al lector a especular sobre posibles interpretaciones. Por esta razón, se podría deducir que el demonio está exponiendo la naturaleza ególatra de su amigo o bien, que el hospedador representa el estado/gobierno que -inicialmente- adopta a los desvalidos, homosexuales, pobres y excluidos, y los asiste hasta que nota que ellos, cuando pueden ver, cuando son conscientes de su situación (el demonio recibe ojos como un regalo del 
hospedador) y pueden valerse por sí mismos, pueden llegar a empoderarse y convertirse en un grupo de poder. Así, figurativamente, los demonios se convierten en una amenaza al adquirir más y más poder. Visto así, se puede afirmar que los gobernantes descubren que no es rentable 'educar' o 'formar' a los excluidos porque éstos, paulatinamente, pueden tomar el control y desplazarlos. Esta interpretación se relaciona con la intención de los grupos hegemónicos de mantenerse en el poder conservando a los excluidos en la marginalidad sin ofrecerles posibilidades de avance social.

Una vez más, las imágenes grotescas son expuestas a través de la representación de seres desvalidos y desmembrados que viven en medio de la basura. Los demonios deconstruyen la idea de progreso y bienestar al proponer que, bajo ciertas condiciones externas, pueden constituir modelos de poder en perjuicio de quienes se revisten de él.

En conclusión, la subjetividad de los excluidos (de)construida en estos relatos aparece siempre rebajada: a nivel corporal, uno está mutilado y el otro ciego; a nivel externo, uno es manejado por un rinoceronte y el otro es controlado por un demonio-fantasma. El rinoceronte y el demonio representan simbólicamente a los entes encargados de ejercer el dominio sobre los desvalidos y desmembrados. Los escenarios en que se desenvuelven estos personajes también refieren a lo grotesco y a la degradación, sin embargo, ellos se muestran felices viviendo en ellos.

\subsection{Las imágenes de guerra, muerte y cadáveres}

Las imágenes deconstructivas más cruentas están conectadas con las representaciones simbólicas de la muerte. El propósito de deconstruir dichas figuras consiste en posicionar las subjetividades otras, ausentes o degradadas, expuestas a situaciones extremas de violencia (como los excluidos en El Salvador) en estados centralizados de presencia, estabilidad y bienestar, sugiriendo con ello, que los sujetos otros ven con normalidad, y hasta con agrado, su condición de degradación y exclusión. Los personajes inmersos en esta realidad son, en su mayoría felices, en medio de la agresión, transgresión y destrucción. Hernández deconstruye mitos y profana imágenes míticas asociadas al cristianismo y a la normatividad hegemónica. Por ejemplo, a nivel religioso, desmitifica rituales como el luto y los funerales, y, a nivel político, invalida la intervención de las autoridades de justicia en los casos de asesinato y corrupción.

Unos cuentos que nos ilustran estas presunciones son Hechos de un buen ciudadano parte I y Hechos de un buen ciudadano II. No es usual encontrarse un cadáver en la cocina, recién muerto y fresco: "aún era mineral el olor de la sangre” (Hernández 2007: 17) y aceptar este hecho con normalidad; ni tampoco publicar en el periódico el anuncio para hallar el “dueño de cadáver de [una] muchacha joven, de carnes rollizas, rodillas saltonas y cara de llamarse Lívida. Fue abandonada en mi cocina, muy cerca de la refrigeradora, herida y casi vacía de sangre. Información al 271-0122” (Hernández 2007: 17). Asimismo, no es común que el número de cadáveres hallados en la cocina aumente a veinte, ni que una persona decida a quién pertenece un cadáver desaparecido para calmar la desesperación de una familia; y mucho menos, que los cadáveres se conviertan en el alimento de pordioseros, indigentes y ancianos: "cuando estuvieron listos [los cadáveres] los corté con cuidado para que no fueran a crujir demasiado los huesos [...] Después herví los trozos, deshilé la carne y la mezclé con una salsa hecha con tomates" (Hernández 2007: 41). Todas estas situaciones son descritas con una frialdad que sugiere que las situaciones son parte de la normalidad, pero se encuentran 
cargadas de ironía. La manipulación de cadáveres no reside en las manos de los "ciudadanos" comunes y, si ellos lo hacen de la forma en que lo hacen los personajes, estos "ciudadanos" no pueden ser tan "buenos".

Un claro ejemplo de intertexto es A Modest Proposal de Jonathan Swift en donde el narrador propone utilizar a los niños de la calle como alimento para saciar el hambre de los pobres. La sátira de alimentar a los desvalidos y excluidos con carne humana, en el cuento II, al igual que Swift, desmitifica satíricamente los rituales cristianos asociados con la muerte y los cadáveres. La gente común se encarga de los cuerpos y decide qué hacer con ellos y esto le confiere el título de "ciudadano meritísimo" (Hernández 2007: 42), aunque, irónicamente, viole las leyes. En sí, las acciones allí descritas degradan y deconstruyen la normatividad cultural-religiosa al anunciar cadáveres, promocionarlos, conmodificarlos y convertirlos en bienes de consumo.

Esta manipulación de cadáveres, en cierto modo, alude a algunos males enfrentados por los salvadoreños: por ejemplo, los crímenes, sobre todo políticos, que quedan impunes debido a la corrupción; de ahí la necesidad de la intervención de las Comisiones de la Verdad para la investigación de los hechos y el planteamiento de una denuncia que genere un precedente de justicia social.

Similar propuesta se encuentra en los cuentos Manual del hijo muerto y Abuelo. En el primero, la reconstrucción del cuerpo de un niño es motivo de emoción, aún más si se sabe que salió completo de la casa dos o seis días antes. Como si fuera un rompecabezas, las piezas deben coserse haciendo costuras "por lo menos dos centímetros antes de los bordes, para evitar que se desgarren las partes cuando se transporte o abrace si ocurre un arrebato de dolor" (2007a: 108). Con ironía, el narrador recomienda que se preste atención a las manos y los pies puesto que "estos suelen - si uno se fija muy bien - revelar escenas de padecimiento pre-muerte del hijo" (2007a: 109). Con estas descripciones, no sólo se subvalora el cadáver del hijo, sino que también se cosifica y degrada, pues se trata de una pieza de tela que debe coserse siguiendo un manual de instrucciones. Es así como el desgarramiento del cuerpo de un niño, convertido en una pieza armable, encarna la tortura y la violencia con que los militares asesinan y descuartizan a los niños. Esta situación podría ser una referencia a la forma en que los militares asesinaban a los desprotegidos en las llamadas Operaciones Limpieza.

En Abuelo, aparece un caso inverso al de la reconstrucción del cuerpo que también revela con ironía la manipulación de cadáveres. En este cuento, el cuerpo es desenterrado y luego mutilado para repartir sus piezas entre los familiares, de manera que todos puedan tener un 'pedazo' del abuelo en sus casas: "busqué la sierra y me dispuse a cortar al abuelo en seis partes, una para cada una de las cinco familias que formaron sus hijos [y] la otra para la abuela, que se decidió por los brazos" (2007a: 59). Contar con alguna pieza del cadáver del abuelo es motivo de satisfacción y alegría. Esto significa que para estos sujetos la profanación, el desmembramiento del cuerpo y la conservación de sus partes les permite experimentar paz y felicidad. Allí, la transgresión asociada al manejo del cuerpo del abuelo subvalora los principios religiosos y culturales y desvirtúa las creencias que rodean la muerte de un familiar. Esta transgresión se da para mitigar el dolor por la ausencia de quien fue arrebatado del seno familiar y que, una vez que fue devuelto, muerto y desmembrado, proveía una llenura emocional, ya que "nada se miraba incompleto con él ahí sentado" (2007a: 58). Al igual que el niño, el abuelo también pertenecía al grupo de los indefensos y desvalidos a quienes los militares debían exterminar.

En estos casos, la manipulación de cuerpos y cadáveres, así como la violación de todos los rituales y creencias circunscritas a la muerte son las formas en que Hernández muestra el 
rebajamiento, la degradación y la violencia. Candelario (2004) manifiesta que la muerte es un motivo de una "celebración irónica como regalo inefable de una historia cíclica de violencia [y el cuerpo] es un signo de mutilación y aniquilamiento”. En este sentido, para Hernández, los cuerpos y cadáveres constituyen la materialización de la memoria pública y privada de quienes fueron víctimas de violencia.

A través de la manipulación de cadáveres, se ejemplifican los rasgos del realismo grotesco bajtiano en donde se transfiere lo elevado y espiritual de los rituales cristianos occidentales circunscritos a la muerte al plano material y corporal en donde la degradación es evidente.

Puede presumirse que los cuerpos y cadáveres pertenecen a sujetos que son y fueron víctimas de la exclusión. Desde esta perspectiva, los cuerpos de los excluidos son representados como un espacio geopolítico receptor de violencia y sus referentes,

en el caso de El Salvador [constituyen un] espacio, [que] es esencia y conducto de toda manifestación de violencia como el hambre, la desnutrición, epidemias mortales, decapitaciones, desmembramientos, torturas y violaciones que mantienen suspendida en la psiquis colectiva salvadoreña la incertidumbre y el terror. (Candelario 2004)

Irónicamente, en los relatos, los excluidos consideran que esa es la forma natural en la cual los 'otros' pueden decidir sobre sus cuerpos. Ellos consideran que el control que coercitivamente se ejerce sobre sus cuerpos es un derecho que tienen los poseedores del poder político; en este caso, el gobierno militar y el grupo oligárquico. La subjetividad está supeditada a quienes manipulan el poder.

Por su parte, también el cuento Lluvia de Trópico delinea los estados de degradación y rebajamiento que desembocan en violencia generalizados en El Salvador, así como la aceptación pasiva por parte del pueblo del status quo y de la realidad. En el texto, después de un aguacero de caca de perro, un decreto oficial les impide a los ciudadanos transitar libremente por la ciudad, con el fin de solucionar lo que los gobernantes llamaron "una enfermedad ambiental"; no obstante, a los ciudadanos no les molestaba el hedor sino que, más bien, "[les] producía una sensación de comodidad muy cercana a lo agradable" (2007a: 70). En consecuencia, cuando el gobierno limpia la caca, los ciudadanos optan por tener perros y ponerlos a defecar en sus casas para "disfrutar" el olor; otros, aprovechándose de la situación, han hecho criaderos de caca y han empezado a negociar con ellos.

Asociado con lo anterior, es posible identificar otro intertexto referente al uso de la escatología ${ }^{12}$ presente en Swift y su obra Gulliver Travels -las referencias a lo grotesco, por ejemplo, el sentimiento de asco por el hedor humano, el uso de la orina para apagar el fuego en la corte real-. Precisamente, las vivas imágenes olfativas y visuales de la caca remiten a los estados de descomposición y decadencia que, de forma deconstructiva, ilustran las condiciones de vida de la sociedad salvadoreña. Hernández deconstruye la idea de estabilidad, comodidad y bienestar al crear como ideal un ambiente repulsivo. Por esta razón, cuando el gobierno interviene para limpiar el excremento, los ciudadanos prefieren volver a las condiciones insalubres. Desean estar inmersos en condiciones escatológicas. Estas condiciones simbolizan la degradación en la cual los sectores populares excluidos se han acostumbrado a vivir.

De forma similar, el contexto descrito por Argueta en El valle de las hamacas, la caca alude a la atmósfera corrupta creada por la alianza estado-militares-oligarquía en la posguerra. La caca simboliza la violencia de mantener a los pobres con hambre pues, como dice Argueta (2008b) en Caperucita en la zona roja, “qqué pasaría si a los pobres se les diera leche? Nadie podría quitarles la costumbre” (2007a: 168), la violencia de perseguir a los 
pobres, a los niños de la calle, a las prostitutas, a los homosexuales (Godoy 2005: 6) en las llamadas 'operaciones limpieza' y asesinarlos por considerarlos criminales menores.

Paralelamente, Hernández critica en su propuesta textual la crisis ecológica generada por la explotación natural en pos del avance capitalista. La destrucción de los recursos, la deforestación, contaminación de aguas, infertilidad, degradación del suelo, erosión y obstrucción de aguas generan un ambiente de caca que afectó directamente a los campesinos sumiéndolos en condiciones peores que las que se tenían -la desnutrición, las enfermedades, la muerte, la pobreza (Faber 1992: 10)-. De allí que los afectados, acostumbrados a vivir en precariedad, prefieran vivir así antes que ser exterminados.

\subsection{La niñez como blanco de violencia}

Dentro de la producción literaria de Hernández, se aborda la transmisión del trauma de la guerra. Los hijos no vivieron el conflicto, lo heredaron de sus padres los abatibles efectos y experimentan, en la posguerra, un terror colectivo. Según Dickson-Gomez (2002), los niños víctimas de la posguerra en El Salvador sufren de dolor e indefensión, pues sus contextos familiares reproducen y reviven esos sentimientos (Traducción mía). Dicho autor señala que, cuando los adultos escuchan a los perros ladrar en la noche, experimentan el terror que sintieron cuando los escuadrones de la muerte llegaban a sus casas, los echaban a la calle y cometían crímenes atroces: matanzas, mutilaciones, decapitaciones y violaciones. En la posguerra, ellos creen que la violencia y los crímenes son perpetrados por los mismos individuos, es decir, los soldados antiguos; pero, en realidad, dichos actos son ahora consumados por los militares y por agentes gubernamentales (Dickson-Gomez 2002).

Los cuentos Lázaro y El buitre ilustran estas realidades. Lázaro es otro personaje con rasgos esquizofrénicos y grotescos que a la vez es mitad hombre y mitad animal, un buitre, y le gusta comer carne de muerto. No obstante, a Lázaro nadie lo excluye por ser buitre (un personaje similar a los zopilotes descritos por Argueta), con clase, con garras, pico y alas; por el contrario, lo aceptan por ser un ciudadano distinguido: "bajo el traje y la sonrisa, era un buitre como los otros" (2007a: 51). Lázaro no solo volaba alto, era gracioso y amable, "caminaba por la ciudad soltando frases corteses al aire y provocando pláticas en cada esquina" (2007a: 51); sino que además, poseía las características de un animal depredador y devorador. Él siempre estaba atraído por la sangre y la carne humana y deseaba comerse los hijos del narrador.

En este relato, a través de la figura de Lázaro, se representa la clase oligárquica. Si bien, las características de Lázaro difieren de las de los militares descritos en otros relatos, por su aparente trato afable, no logra esconder su carácter devorador y depredador: Lázaro lame con avidez la sangre de la niña (hija del narrador) y encuentra mucha dificultad en soltarla. Posteriormente, el narrador mata a Lázaro; en esta ocasión, la violencia está justificada porque la emplea para proteger a su familia y a sus hijos. En síntesis, el cuento describe el 'stress' postraumático (problematizado anteriormente por Dickson-Gomez) del padre, quien movido por el terror actúa antes de que se produzca un ataque en contra de sus hijos.

Por otra parte, los niños también recrean los efectos traumáticos vividos en la posguerra. Melissa, el personaje principal de Melissa: juegos 1 al 5, tan solo tiene cuatro años, pero a su temprana edad puede protagonizar las más vívidas y tétricas escenas de muerte. Por ejemplo, en uno de sus juegos ella aparece desnuda "boca abajo, con la lengua entre los dientes y un cinturón del padre que le sale desde la parte más alta de las piernas, donde lo tiene sujeto" (2007a: 97). Ahí, Melissa está representando a un gato arrollado. En otro juego, 
ella cae a los pies del padre de improviso con los ojos abiertos y clavados en él, simulando ser una paloma muerta por una pedrada. Pero, quizás, la escena de muerte más representativa es cuando Melissa juega con treinta muñecas desnudas y muertas. Las más pequeñas están en gavetas (refrigeradores mortuorios); otras siete, sobre una sábana para ser atendidas (cama mortuoria); otras tres, recién llegadas, presuntamente de la morgue, en bolsas; cuatro más, listas para que se las lleven los parientes, y las últimas seis, están debajo de la cama porque ya fueron enterradas.

Los juegos de Melissa se fundan en situaciones cotidianas vinculadas con la muerte. En este caso, las escenas son más fuertes aún, porque las protagoniza una niña, que se supone es símbolo de inocencia. Mediante la parodia las escenas deconstruyen la infancia de los niños salvadoreños, pues su mundo no se encuentra conformado por la imaginación y la inocencia, sino por la degradación y la muerte. En otras palabras, para que un niño practique este tipo de juegos tiene que haber sido expuesto a eventos aterrorizantes que le han dejado graves daños físicos o psicológicos (Dickson-Gomez 2002).

Otro ejemplo perturbador de la exposición de los niños a la violencia lo constituye la niña protagonista del relato Un ángel en el baño. Diana, de ocho años, asegura que juega con un ángel en el baño, pero éste resulta ser un desconocido. Aunque Diana (la mujer que la cuida) sorprende al extraño, el relato deja entrever la facilidad con la cual la niña puede ser violentada por un degenerado sexual. Con esta historia, se deconstruye la posición del ángel guardián, el compañero de juegos de Diana, al caracterizarlo como un pervertido y potencial violador. Al utilizar el nombre de "Ángel", el lector se confunde y duda acerca de la existencia del amigo de la niña. La niñez en estos relatos está representada como una "carnada" puesto que aparece expuesta e indefensa ante peligros inminentes e inmediatos que parecen abundar en el entorno.

\subsection{Olvida Uno: fronteras entrecruzadas en el exilio}

Utilizando representaciones de personajes un tanto más realistas y referenciales, Hernández describe en el texto Olvida Uno las experiencias vividas en New York por un grupo de inmigrantes provenientes de otros mundos. De hecho, la autora confiesa en una entrevista, que en esa ciudad pudo experimentar "el placer sencillo de caminar sin tener que estar pendiente de que algo terrible fuera a suceder en la siguiente acera, como en mi ciudad" (Hernández 2007c). La secuencia de cuentos narra la vida en el exilio de un grupo de personajes, permeada de violencia invisibilizada en la dinámica de sus relaciones interpersonales y laborales. Los personajes describen sus vivencias y realidades como representantes de una voz colectiva oprimida por el sistema.

Las narraciones en Olvida Uno, la mayoría presentadas mediante el flujo de la conciencia con estructuras trastocadas ${ }^{13}$, dibujan sujetos (al igual que en De Fronteras) aislados, desarraigados, perdidos y excluidos en un contexto alienante que los absorbe y los consume; pero que, al mismo tiempo, les demanda todo su potencial físico y mental para subsistir en medio de un sistema capitalista salvaje y competitivo. En consecuencia, los personajes parecen buscar alternativas de escape a la opresión en sus espacios personales y privados.

Al igual que De Fronteras, el texto La han despedido de nuevo presenta a un personaje que muestra rasgos esquizofrénicos. En este caso, se trata de una mujer que al sentirse perseguida por un hombre lobo cambia constantemente de trabajo y, en el proceso, conoce a varios inmigrantes que relatan sus desgracias y sus escasas satisfacciones en New York. Para citar algunos ejemplos, encontramos a los personajes como el siro Samah, a Marina, hija de la 
griega, o a Michelle, la de descendencia rumana, todos ellos meseros y meseras cuando llegan a la ciudad, pero con posibilidades de ascender laboralmente si aprenden el idioma o, en el caso de las mujeres, si dejan ver sus piernas u otras partes de sus cuerpos a sus jefes. Algunas, como Lourdes, han utilizado el sexo para lograr mejores posiciones en el trabajo: "Eso sí, cógetelo bien, que de eso depende que [él] siga contigo. Y eso hice. Me cogí al chino por necesidad los dos años que me llevó aprender inglés y aprobar el curso en la escuela de belleza y, luego, [...] lo dejé" (Hernández 2005: 41). De dicha forma, el texto propone que el lobo perseguidor, en estos casos, es el sistema que atrapa a los inmigrantes a nivel laboral, económico, legal y social para devorarlos, es decir, para absorberlos. Ingenuamente, los personajes creen en el sistema y terminan siendo absorbidos por él.

Para estos inmigrantes, la alternativa de mitigar la opresión generada por aislamiento, la enajenación y la soledad es buscar opciones de compensación en los espacios íntimos y privados. De esa forma, desarrollan relaciones conflictivas que transgreden la normatividad y las convenciones que enmarcan el noviazgo, el matrimonio y la amistad. Por ejemplo, el narrador de La mía era una puerta fácil de abrir, a pesar de mantener abiertas las puertas de su apartamento (físicas y simbólicas) para hablar con sus vecinos durante "visitas cortas y en horarios de supermercados" (Hernández 2005: 11), se molesta cuando una niña empieza a hurgar con sus ojos y sus manos en sus cajones, es decir, cuando metafóricamente, invade su intimidad, irrumpe dentro en sus secretos y temores; entonces, él empieza a proteger los cajones con cerraduras y llaves. Algo similar ocurre con Claudia, en el cuento Jon prefiere que no nos veamos por un tiempo. Ella guarda su "universo" secreto en el baño al que no tiene acceso nadie, ni siquiera su amante casado: "No quiere que sienta que invade sus espacios, por eso nunca cede a la tentación de echar un vistazo a sus cuadernos ni considera entrar al baño" (Hernández 2005: 21). En ese espacio privado, ella guarda "su universo", su felicidad, sus fantasías: su intimidad.

Para otros personajes, los espacios íntimos se encuentran encerrados dentro de sí mismos. Ese es el caso de Nara, en el cuento Es por Nara. Aquí, esta mujer ecuatoriana se siente amenazada al escuchar voces que la atormentan y despiertan sus temores. Su abatimiento y perturbación interna que podrían estar asociados a la salida de su país y al hecho de vivir en el exilio como inmigrante. También, Tarsila, el personaje de Filipinas en Solo a ella, debe huir a causa del tipo que se le aparecía siempre distinto, pero con los mismos ojos (Hernández 2005: 99) y la aterrorizaba. Se trata de un tipo que persigue a Tarsila como su sombra y, al igual que Nara, huye porque sus ojos le permiten mirar sus temores internos.

Los espacios físicos e íntimos donde se mueven estos personajes están descritos con ambivalencia y ambigüedad, con el propósito de obligar al lector a construir el texto. ¿Cuáles son los temores, las amenazas que sienten estos personajes?, ¿serán producto de la ansiedad de vivir en el exilio y en la enajenación? Ante la incertidumbre, estos sujetos justifican las transgresiones que cometen en la intimidad, pues ellas implican catarsis y subsistencia. De allí que encontremos diversas violaciones a la normatividad: ilegalidad migratoria, amores furtivos, adulterio, prostitución, lesbianismo, homosexualidad, traición y venganza.

\section{Consideraciones finales}

Si bien los estilos discursivos de los dos autores difieren en sus narrativas, es indudable que ambos cuestionan el orden o, más bien, el desorden generado por las posturas gubernamentales y políticas identitarias excluyentes. Las obras de estos escritores centroamericanos denuncian 
con claridad las políticas opresivas que propiciaron los conflictos revolucionarios en El Salvador y el consecuente estado de descomposición social que imperó. El discurso referencial utilizado por Argueta sirve de antesala para conocer el contexto del conflicto bélico desde la perspectiva de sus diferentes personajes, que se posicionan en locaciones sociales representativas de identidades diversas. Su aporte instruye al lector sobre la historiografía de la guerra en El Salvador. El tipo de discurso utilizado por Hernández, por su carácter figurativo, provoca un acercamiento sensorial a las imágenes que describen las realidades contextuales que ella quiere evidenciar. Su discurso va más allá que la mera comunicación de los hechos y sirve como complemento al texto de Argueta. Además, la ilustración de la subjetividad que nos ofrece Hernández, por las razones obvias relacionadas a su edad, representa realidades cotidianas simbólicas dentro de un contexto que se distancia en términos de la época de los conflictos bélicos que representa Argueta, pero que a la vez se derivan de ahí.

Ambos autores examinan la violencia de la exclusión identitaria en sus discursos, aunque difieren en la forma estilística con la cual construyen sus textos. También, aluden a los procesos a partir de los cuales se configuran las identidades y la subjetividad durante la guerra y la posguerra. El enmarque de la subjetividad está signado por la degradación generada por el peso de la violencia de la guerra, seguido por la imposición de un gobierno militar autoritario, asociado a la oligarquía, que legitimó el poder de acuerdo con sus intereses y propició la polarización social y, consecuentemente, la exclusión, sin que mediara alguna agencia de control o regulación judicial. Los grupos excluidos representados en los textos de Argueta manifiestan la resistencia a este esquema político con un grado de rebelión expreso en los conflictos bélicos, pero también, a juzgar por el tono de la narrativa, con un matiz de resignación ante el problema. En Hernández, los textos develan una resignación irónica ante la violencia, que aunque podría asociarse a pasividad y conformidad, más bien provoca repudio ante ella. La ambivalencia en la representación de las subjetividades excluidas -los subalternos- consiste en que estas parecen aceptar las condiciones de su entorno y tienden a encontrar confort en él pero, a la vez, sus representaciones inducen al lector a despreciarlas.

Al percibir la violencia y la exclusión que sufren diferentes poblaciones salvadoreñas (niños, viejos, mendigos, mujeres, homosexuales, personas con discapacidad y pobres, en fin, los oprimidos por los grupos en el poder el estado, los militares y los burgueses durante los conflictos armados y posterior a ellos) no dejo de asociar la situación de su subjetividad y sus representaciones identitarias con el realismo grotesco que plantea la degradación y al rebajamiento característico de la sátira y parodia bajtiana. No obstante, por medio de la evocación satírica y burlona de la risa ritual que producen dichas imágenes, surge un aire concientizador y transformador que anticipa "épocas de mutación y cambio" (Bajtín 1995) y prevee un porvenir en vías de formación.

\section{Notas}

1. Según el artículo Identidad política y política de identidades de la Revista de Letras Libres, las políticas identitarias se refieren a la reivindicación del poder basada en una identidad concreta, sea: nacional, de clan, religiosa o lingüística; por lo tanto, se vinculan las políticas identitarias con la hegemonía. del discurso colonial" que ha impulsado un sujeto fragmentado y descentrado excluido del proyecto modernista eurocéntrico. 
3. De acuerdo con Journal of Latin american Anthropology (1999: 78), un ladino es alguien "blanqueado" e habla español, usa ropa europea, es cristiano o secular y moderno (Traducción mía).

4. Una visión de la sociedad expresada en términos de adquirir características de consumo y patrones de vida análogos a los de las naciones metropolitanas cuya ideología no sólo se vio proyectada en el consumo, sino también en la transformación de los medios de comunicación (Arias 1998: 33-35).

5. Manlio Argueta nació el 24 de noviembre de 1935, en la ciudad de San Miguel, cabecera del departamento oriental del mismo nombre. Argueta fue miembro de la autodenominada Generación Comprometida y del Círculo Literario Universitario, dos de los grupos literarios más reconocidos en El Salvador, surgidos entre 1950 y 1956, de influencia sartreana y que participaron en activismo social, cultural y político. En 1967, su novela El valle de las hamacas obtuvo el primer premio en el Certamen Centroamericano de Novela, convocado por el CSUCA. Fragmentos de esta obra fueron divulgados por la revista sansalvadoreña La pájara pinta, pero la versión en libro fue realizada por la Editorial Sudamericana (Buenos Aires, 1970), por entonces encargada de la divulgación internacional de los autores del "boom" narrativo latinoamericano. (COMISIÓN CÍVICA DEMOCRÁTICA "NO SOMOS POLITICOS, SOMOS PUEBLO HACIENDO POLITICA").

6. Trin. T. Minh-Ha (1992) propone que la fragmentación "it's not a question of fragmentation versus synthesis but rather, of how one understands what happens within the notion of fragmentation. If one sees a fragment as being the opposite of a whole, then I have no affinities with the term, since it carries with it a compartmentalized worldview. But if a fragment stands on its own and cannot be recuperated by the notion of a totalizing whole, then fragmentation is a way of living with differences without turning them into opposites, nor trying to assimilate them out of insecurity (157).

7. Las referencias a la novela de Caperucita en la zona roja se citarán por el nombre del autor, el año de publicación y el número de página solamente.

8. Claudia Hernández es una escritora salvadoreña. Nació en San Salvador el 22 de julio de 1975. Licenciada en comunicaciones por la Universidad Tecnológica de El Salvador, realizó también estudios de Derecho. Ha escrito De fronteras, Otras ciudades, Olvida uno y La canción del mar. En el año 1998 recibió uno de los premios Juan Rulfo de Radio Francia Internacional, en la categoría de cuento. En 2004, obtuvo el prestigioso premio Anne Seghers, en Alemania, por obra publicada. Ha sido antologada en España, Italia, Francia, Estados Unidos y Alemania (2010 tribunalatina.com).

9. Según la propuesta de Mijail Bajtín (1995) en su libro La cultura popular en la Edad Media y en el Renacimiento. El contexto de Francois Rabelais, dentro de la cultura cómica popular, se organizaban ritos y espectáculos exteriorizados en festejos carnavalescos, obras verbales cómicas y manifestaciones del lenguaje con formas de un vocabulario particular como, por ejemplo, los insultos, juramentos, etc. La cultura carnavalesca originó una lengua propia, sus formas están impregnadas de la comprensión gozosa de la relatividad de las verdades, sus formas están situadas en la frontera entre el arte y la vida expresando una concepción de mundo ligadas, en todas sus fases históricas, a períodos de crisis, trastorno en la naturaleza, en la sociedad y el hombre.

Aunque esta organización cómica se diferenciaba totalmente de las ceremonias oficiales de la Iglesia y el Estado Feudal, las expresiones de la cultura cómica servían para convertir a las autoridades y divinidades en objetos de burla y blasfemia mediante la risa ritual. La naturaleza de la risa ritual es totalmente ambivalente: está llena de humor satírico, es burlona, escarnece, pero es a la vez ligera y está destinada a divertir; sin embargo, también influye en las más altas esferas del pensamiento y culto religioso. La risa está imbuida en la cosmovisión carnavalesca predominantemente en las parodias e imitaciones laicas que escarnecen al régimen feudal y el heroísmo (Bajtín 1995: 20). Aparece también como herencia directa de la cultura cómica popular la concepción estética asociada a la vida práctica, llamada el realismo grotesco proyectado a través de imágenes cuyo rasgo más sobresaliente es la degradación. 
10. Jacques Derrida explica cómo opera la noción de la deconstrucción y los sistemas que controlan la hegemonía y el centro a través de la historia. Él explica que dichos sistemas son estructuras centralizadas que dependen de una lógica paradójica entendida en la relación que existe entre el centro que encarna la "verdad" y la estructura opuesta a él. La estructura central plasma el término privilegiado y presente y su opuesto ausente plasma el suplemento. El término central genera el logocentrismo. Ambos términos caen en una relación jerárquica de presente/ausente, superior/inferior. El propósito de la deconstrucción es la subversión de esta relación jerárquica:"instead of appearing as a mere representation of truth [...] the privileged term is obscured by the supplement, providing a field of limitless play, which is characterized by the movement of difference" (Childers 1995: 74).

11. La sintomatología de los pacientes esquizofrénicos en la literatura fue tomada de las propuestas de Fredic Jameson y sus análisis de la presencia de la esquizofrenia en personajes en la crítica ofrecida por María Teresa Vilariño Picos (2007: 46-47).

12. Aquí se utiliza la escatofagia derivada de la escatología que remite a la ingesta o utilización de excrementos para representar las condiciones y prácticas grotescas y degradantes en los seres humanos.

13. La referencia a estructuras trastocadas se remite a que un relato termina en medio de otro relato que comienza y que este puede que no concluya.

\section{Bibliografía}

Acevedo, Ramón Luis. 1994. "Orígenes de la nueva novela centroamericana (1968 -1980)". Revista La Torre (Universidad de Puerto Rico). Nueva Época: 7 (29): 148-155.

Amnistía Internacional. 1996. EL SALVADOR El espectro de los «escuadrones de la muerte. Diciembre. RESUMEN ÍNDICE DE AI: AMR 29/15/96/s DISTR: SC/CO/GR (50/96).

Arana, Ana. 2001. The New Battle for Central America. Council on Foreign Affairs. http:// www.foreingaffairs.com/articles/57420/ana-arana/the-new-battle-for-central-america.

Argueta, Manlio. 2008a. El valle de las hamacas. San Salvador: UCA Editores.

2008b. Caperucita en la zona roja. San Salvador: UCA Editores.

Arias, Arturo. 1998. Gestos ceremoniales. Narrativa centroamericana 1960-1990. Guatemala: Arremis-Edinter.

Bajtin, Mijail. 1995. La cultura popular en la Edad Media y en el Renacimiento. Madrid: Alianza Editorial.

Biólogos de El Salvador. 2009. "Ensayo de la guerra civil de El Salvador". http:// guerracivilelsalvador.blogspot.com/2009/06/ensayo-de-la-guerra-civil-de-el.html 
Browitt, Jeffrey. 2000. "Literatura nacional y el ocaso del discurso de la nación-estado en Centroamérica". Universidad de Monash, Australia. En: Istmo Revista virtual de estudios literarios y culturales centroamericanos. No. 1 (enero-junio). http:// collaborations.denison.edu/istmo/.

Candelario, Sheila. 2004. "Violencia, globalización y literatura: O el dilema del Eterno Retorno en El Salvador". En: Istmo Revista virtual de estudios literarios y culturales centroamericanos. No. 8 (enero-junio). http://collaborations.denison.edu/istmo/.

Castro, Santiago. 2005. La hybris del punto cero; ciencia, raza, e ilustración en la Nueva Granada (1780-1816) por Lina R. Medina M. Bogotá: Editorial Pontificia Universidad Javeriana.

Childers, Joseph. and Gary Hentzi (ed). 1995. The Columbia Dictionary of Modern Literary and Cultural Criticism. New York: Columbia University Press.

Cortez, Beatriz. 2002a. Estética del cinismo: la ficción centroamericana de posguerra. Ponencia presentada en el V Congreso Centroamericano de Historia 18-21 de julio de 2000. San Salvador: Universidad de El Salvador (no publicada).

2002b. La Construcción de la identidad como fuente de violencia y su representación en la literatura Centroamericana de posguerra. Ponencia X2. Congreso Internacional literatura Centroamericana. Instituto Iberoamericano Berlín.

Craft, Linda. 2000. "Al margen de la función testimonial en dos novelas recientes de Manlio Argueta”. En: Román-Lagunas, 80-85.

Dickson-Gomez, Julia. 2002. "The Sound of Barking Dogs: violence and Terror among Salvadoran Families in the Postwar". Medical Anthropology Quarterly 16 (4): 415-438.

Dussel, Enrique. 1994. El encubrimiento del otro. Hacia el "origen del mito de la modernidad". La Paz: Editorial Plural.

Garita, Nora y Anacristina Rossi (eds.). 2007. El Lado oscuro. Ensayos sobre violencia. San José: Uruk Editores.

Godoy, A. S. 2005. “La Muchacha Respondona: Reflections on the Razor's Edge betweenCrime and Human Rights". Human Rights Quarterly. 27 (2): 597-624.

Hernández, Claudia. 2005. Olvida Uno. San Salvador: Indole Editores.

2007a. De Fronteras. Guatemala: Piedra Santa. 
2007b. "Eco de una ciudad ajena, a propósito de Olvida Uno". Piedepágina, Revista de libros. No. 12, 1 Agosto. Bogotá http://www.piedepagina.com/numero12/html/ claudia_hernandez.html.

Jameson, Fredric. 1996. Teoría de la postmodernidad. Trotta, Madrid.

Kaye, Mike. 1997. The Role of Truth Commissions in the Search for Justice, Reconciliation and Democratisation: The Salvadorean and Honduras Cases. London: Cambrige University Press.

Lee U. Anna. 1993. Las novelas de Manlio Argueta: La historia, cultura e identidad salvadoreñas (January 1, 1993). Dissertations available from ProQuest. Paper AAI9331854. http://repository.upenn.edu/dissertations/AAI9331854.

Leiva, Héctor M. 2005. "Narrativa centroamericana post noventa: Una exploración preliminar”. América Central en ojo de sus propios críticos. Guatemala, Ediciones Papiro S.A.

Mackenback, Werner. 2004. "Después de los pos-ismos: ¿desde qué categorías pensamos las literaturas centroamericanas contemporáneas?”. Istmo Revista virtual de estudios literarios y culturales centroamericanos. No. 8 (enero-junio). http:www.denison.edu/ istmo/.

Mignolo, Walter. 2005. La idea de América Latina. Barcelona: Romanyá Valls.

Muslip, Eduardo. 2008. “Caperucita en la zona roja de Manlio Argueta: La propiedad de la Literatura”. Argentina: Universidad Nacional de General Sarmiento. Istmo Revista virtual de estudios literarios y culturales centroamericanos. No. 17 (julio-diciembre). http://collaborations.denison.edu/istmo/.

Ortiz W. Alexandra. 2002. "Transiciones democráticas / transiciones literarias. Sobre la novela centroamericana de posguerra". Istmo Revista virtual de estudios literarios y culturales centroamericanos. No. 4 (julio-diciembre). http://denison.edu/istmo/.

Roman-Lagunas, Jorge (ed.). 2000. Visiones y revisiones de la Literatura Centroamericana. Guatemala: Editorial Oscar de León Palacios.

Trinh T. Minh-Ha. 1992. Framer Framed. Great Britain: Routledge.

Vilariño P. María Teresa. 2007. "Espéculo". Revista de estudios literarios. Universidad Complutense de Madrid. http://www.ucm.es/info/especulo/numero36/esesquiz.html. 